\title{
The Spread of Deism in the Reformed Church in the South Eastern Region of the Kingdom of Hungary at the Turn of the 18th-19th Century
}

\author{
Ádám Hegyi \\ University of Szeged
}

\begin{abstract}
Deism is one of the branches of radical Enlightenment which states that God creates the World, but he does not intervene into its operation. Theological dogmas are completely useless because these rules are not necessary for the prosperity of people. These ideas were very dangerous to Christianity; however, they were widespread in many parts of Europe in the 18th century. The Reformed Diocese of Békés was located in the south eastern area of the Kingdom of Hungary, whose followers practised an essentially rural way of life; therefore, they hardly read any scientific and philosophical works. In spite of this fact, the spread of the ideas characteristic of deism can be observed in numerous dioceses. The reception of deism in southeast Hungary can be witnessed not in the traditional intellectual documents (school curriculum, translations, and philosophical treatises), but in the documents of the ecclesiastical government: Church attendance records, documents of the proceedings of the ecclesiastical courts. With the detailed analysis of the ecclesiastical administration documents of the Reformed Church, this study investigates how folk religion relates to deism and the criticism of religion by the radical Enlightenment.
\end{abstract}

Keywords: deism, radical Enlightenment, folk religion, Reformed Church, the Kingdom of Hungary

A considerable difference can be observed between radical and moderate Enlightenment with regard to their views on religion, because radical philosophers criticized not only the Church, but also questioned the legitimacy of religious belief. Though deism never got to deny the existence of God, but its philosophical tenets were deemed very dangerous from the viewpoint of the Christian Church. As a result, in the eyes of the church leaders, deism and radical Enlightenment were the same, even if not all radical philosophers were deists. According to the deists, God creates the World, but God's intervention into everyday life cannot be proven, hence, religious dogmas are entirely superfluous. For achieving Salvation, it is sufficient to follow and keep good morals. In other words, it is not necessary for people to comply with the tenets of either Christianity or any other world religion. In their view, God intervenes in the creation of neither the Bible nor any other religious holy texts, therefore, people ought to return to the natural religion, the main characteristic of which is that it is devoid of all theological restrictions. ${ }^{1}$

Ádám Hegyi, Ph.D., senior assistant professor, Department of Cultural Heritage and Human Information Science, Faculty of Arts, University of Szeged, Hungary; main research field: History of the Reformed Church, History of Reading, History of the University and the Library, and Cultural History. Email: hegyi@bibl.u-szeged.hu.

The study was supported by the Bolyai János Research Fellowship of the HAS (Hungarian Academy of Sciences) and translated by Zoltán Cora. 
The intellectuals of the Kingdom of Hungary in the 18th Century know these ideas; however, the views of ordinary people are fairly unknown, hence, the retrieval of new information from the dioceses of the Reformed Church might be of interest in this respect. The research into the history of reception of intellectual trends uses a complex methodological toolbar. If one intends to reconstruct the traces of the spreading of deism in the Reformed Church in the south eastern part of the Kingdom of Hungary, then one should mainly take church-administrative documents into consideration and not philosophical treatises, because the latter are barely written in this area. The reason for this is that the Reformed Church is present in basically rural and agricultural settlements in this part of the country, and the members of the Church follow no or hardly any civic, urbanized lifestyles. Only one major Reformed high school functioned in this period, which was located in Hódmezővásárhely. What is more, neither printing press nor bookseller worked in the settlements of the diocese in the examined period, the closest printing press to the congregations could be found in Szeged and Arad (Szabó 2008). However, before analysing the sources, it is worth summarising first why the appearance of the philosophy of deism in Christian philosophy is interesting.

In early modern Europe, religiosity was the inseparable part of the cultural system, all social attitudes and cultural processes appeared in a religious form. Religiosity had an essential role in the organization of everyday life. Since religious faith influences human actions, therefore in the analysis of social changes it is essential to consider the correlations among faith, Church, and society (Geertz 1966). The only way to achieve the latter is that the reception of Hungarian deism is approached from the viewpoint of lay religiosity characteristic of broad layers of the population.

According to our current knowledge, the process of de-Christianisation cannot be discerned in the territory of the Hungarian Kingdom in the 18th century, unlike in other areas of Western Europe, such as Provence, where this phenomenon could be identified in the case of not only elite intellectuals, but also larger groups of the society. Obviously, Enlightenment and Josephinism ${ }^{2}$ also transformed lay religiosity in the Carpathian Basin, but it by no means indicated that the church would have lost its social positions. ${ }^{3}$ Nevertheless, it is a fact that the radical Enlightenment confronted religiosity and the church in Western Europe as well as in Hungary. The main difference was that in the eastern parts of the Habsburg Monarchy, the majority of the intellectuals did not dare to openly confess their anti-religious ideas, while in the West much more publications were printed in such topics. ${ }^{4}$ All works dealing with the history of the Hungarian Reformed Church mentioned that at the turn of the 18th-19th century a certain kind of anti-religiosity could be perceived, but it did not affect the lives of the congregations to such an extent that believers would have left the congregations en masse (Bucsay 1977, Vol. 1. 277-80). However, in the 19th century, theological changes rooted in Enlightenment philosophy could have already been observed to a greater extent in the Hungarian Reformed Church, as these ideas were incorporated into the one of the contemporary theological trends, known as liberal theology. The orthodox theologians rejected these changes, but they were unable to prevent the spread of the above mentioned ideas. Despite the fact that both liberals and the orthodox opposed materialism and atheism, their religious conceptions considerably differed. The latter needed not to be detailed here; it was sufficient to draw attention to the fact that the representatives of the Hungarian Reformed liberal theology were accused of deism by orthodox theologians, as it could be supposed on the basis of certain statements of theirs that they identified themselves with a dogma which said that God only created the World but the World is functioning without his intervention (Kovács 2010, 89-92; 108-11).

Deism that appeared among the Calvinists ${ }^{5}$ living in the south eastern part of the Kingdom of Hungary 
may be relatively easily examined, because in that geographical area the Reformed Church was grouped into a single church-administrative unit, the Békés Reformed Diocese. On the contrary, the Roman Catholic Church Administration did not constitute a single block, since the territory from the Körös Rivers to the Lower Danube belonged to the bishoprics of Vác (Waitzen/Vacov), Nagyvárad (Oradea/Großwardein), and Csanád (Tschanad/Cenad) respectively. Thus, the south eastern part of the Hungarian Kingdom can be defined as the area bordered by the Körös Rivers in the north by the Tisza in the west, by the Lower-Danube in the south, and by the Carpathian mountains in the east. The size of this territory equaled that of Belgium, but only 30 reformed congregations existed in the area at the turn of the 18th-19th century, which meant that it was relatively easy to explore their archival sources. As for the religious denominations, this area of the kingdom was rather heterogeneous, since Roman Catholics, Greek Catholics, Greek Orthodox, Reformed, Lutheran, and Jewish believers were living there. However, due to the limits of this study, only the Reformed congregations were examined. ${ }^{6}$

The representatives of Enlightenment in the Hungarian Kingdom considered the printed book as a tool for raising the literacy of common people. Yet a paradox situation occurred in the program of popularising reading, since leading intellectuals were socialized to ignore the uneducated people. This strange situation was well shown by the tendency that numerous books aimed to enlighten the folks which had been translated to Hungarian, and while in the original versions, the role of the book and reading was discussed as a central motif, in the Hungarian translations (both in the Catholic and the Reformed works); the role of book was marginalised; and the emphasis put on reading was replaced by the importance of word-of-mouth transfer of information respectively. The transformation of the methodology pertaining to the enlightening of the people in Western Europe was probably justified by the fact that in Hungary reading and praying were practically synonyms in the world of peasants, and the book was rather regarded as a mystical kind of thing, not an article for personal use. ${ }^{7}$ When researching the legal affairs and cases in the early modern Hungarian Kingdom, Ildikó Kristóf found that in many cases, legal cases were closed with formulas which used oral and written demonstration of proof simultaneously. In other words, the transition between literacy and illiteracy could also be observed in certain groups of the society even at the beginning of the 19th century (Kristóf 2002). Therefore, from these considerations, it followed that the Békés Reformed Diocese was not an ideal terrain for the reception of the philosophical ideas of deism: It can be assumed that within the thin layer of literate people, only a very few read works, which discussed the tenets of deism in detail. Oral information and hearsay had a much greater impact on public opinion than written texts. This view was also confirmed by the research into the qualification of the lower Catholic clergy at the end of the 18th century. The research concluded that the priests were not able to distinguish between Enlightenment's and radical Enlightenment's criticism concerning the church and anti-religiosity (Lukácsi 2008, 61-63).

As Miguel Benitez pointed out, critical, philosophical appropriations towards religion which emerged in the century of Enlightenment could only spread appreciably in the form of manuscripts in the Habsburg Empire, because in many cases, one can conclude on what philosophers really thought about religion only from the thoughts expounded in the manuscripts. However, no such documents survived in the south eastern part of the Kingdom of Hungary (Benitez 1996). Nevertheless, clerical disciplinary records were available in which indications of deism can be found.

The most important tool for shaping the morality of the Reformed Church was the strict enforcement of clerical discipline by which pastors controlled, for instance, the sexual debauchery of the church members and 
the practicing of the evident forms of ecclesiastical life, such as taking part in the sacraments and the regular attendance at worships. A mutual dependency developed between the pastor and his congregation, because not only the priest, but the community was also keeping a close eye on the other party's moral debauchery. This complicated relationship led to regular conflicts between the pastor and the congregation, as well as among the members themselves. If the conflict could not be solved at once locally, the disputant parties applied to the diocese for arbitration. At this stage, the case was already going to the ecclesiastical court, where the disciplinary investigations of the church were conducted. After the hearings of witnesses, the leaders of the diocese adjudicated, meaning that they chastised the sinners and sought to resolve conflicts (Kiss 2008). As for the disciplinary misdemeanours, a substantial difference can be discerned between the Western European and the Hungarian Reformed Church in terms of the number and severity of cases: In the Carpathian Basin, the sanctioning of the disciplinary misdemeanours within the church was much slighter and less frequent than, for example, in the canton of Bern. Swiss Calvinist people had debates with their pastor more often and definitive separations also happened more frequently: The pastor was separated from congregation and was relocated elsewhere (Schmidt 1998).

In the settlements of the Békés Reformed Diocese located along the Körös Rivers (Öcsöd, Gyoma, Békés, Köröstarcsa, Gyula), such church disciplinary cases were found, in which deist ideas characteristic of folk religiosity can be identified. Besides, one should mention the congregation of Debeljácsa (Debeljača) in the military border-guard zone, where more radical critical ideas spread than that of deism. As a result, the question arises: Why the philosophy of deism could not be detected in other congregations of the diocese? May one speak about some kind of anti-religious philosophy in the other 24 parishes?

I think that the answer can be found in the peculiarity of folk culture. As it has been shown above, a special transition is brought about between orality and literacy in Hungary, as a result of which, in the world of peasants information is predominantly spreading orally, rather than in a written form. It may be easily the case that there has been simply no trace of deism left in the written documents of the other parishes. This supposition is further confirmed by an incident which occurs in the parish of Szentes. In the 1820 s, a few wealthier farmers refused to administer the Communion, and their decision could be retraced to the influence of the perspective of radical Enlightenment (but not deism), which did not regard it necessary anymore that people should live their lives strictly within the framework of the parish (Hegyi 2013). As Szentes lies 30km south from Öcsöd, it might be concluded that various anti-religious ideas, including even deist thoughts, could occur not only along the Körös Rivers and the military border-guard zone, but also in the settlements located between these rivers and the border-guard zone. In this respect, it is irrelevant that the Körös Rivers and the Turkish-Hungarian border lay hundreds of kilometres far from each other, because distance is not an obstacle that orality could not master.

Consequently, one should investigate what forms of deism could be observed in the above mentioned parishes of the Békés Reformed Diocese.

The first incident happened in Öcsöd: It was known from the report of the questioning of the witnesses written by the notary of Öcsöd on the 9th of November, 1794, that the presbyter, András Konkoly, provided incriminating evidence against János Papp, the chaplain-teacher. According to Konkoly, Papp was his guest one night, when Papp got drunk and in his rapture he denied resurrection and called Moses an impostor. János Pap did not deny the charges brought against him and only said in his defence that he heard these statements from a student coming home from abroad, but he himself never read about such things. No more information about 
this incident can be obtained from the protocols of the canonical visitation, because the only thing that was documented in it was that a church disciplinary problem arose in the congregation, with no reference to his statement about the resurrection. The consequence of Papp's scandalous behaviour was that he was deposed of his office in 1795. However, he was not bothered by this incident, as he ran away from Öcsöd and even managed to get a new job as a pastor again in Simontornya. ${ }^{8}$

In Gyula, the leading intellectuals of the town fell under suspicion, when in 1795 József Réz, the local oculist was accused by having sympathised with the French Jacobin movement and having taken part in the Hungarian Jacobin conspiracy. Obviously, József Réz was subsequently imprisoned. Moreover, an investigation was launched against the Jacobin movement in Gyula, during which the main caretaker of the Békés Reformed Diocese, Lörinc Domokos, and the archivist of Békés county, the also Calvinist Mihály Kazay also fell under suspicion. Nevertheless, historical research had already ascertained a long ago that none of them took part in the Jacobin movement and that their way of thinking was not even remotely similar to that of the radicals of the French Revolution. ${ }^{9}$ Nonetheless, their case was worth looking at for the purposes of this study because during the questioning of witnesses, József Sziber, a salt officer, and Ferenc Glück (Klick), an inhabitant of Gyula, gave testimony against József Réz which contained elements of religious criticism. Réz reportedly said about the prayer book of Glück that it was entirely unnecessary to read it because it contained only silly, fictional things and all pastors were impostors. ${ }^{10}$

The ecclesiastical court formulated ten charges against the teacher of Békés, János Fábián in 1796, a number of which strongly resembled the theses of deism. Here only those are listed which are relevant to this study: According to the accusers, Fábián claims that the writing of the Bible is only inspired by humans; religion is only a human invention; and henceforth no article of the faith can be proven; Jesus is not God and the deniers of Trinity are closest to the "true religion." According to the indictment, Fábián not only preached these ideas, but in order to disseminate these views, he organized a small community in the town. The investigation began with denunciations of the secular leaders of the Békés Reformed parish (caretaker, presbyters), in which the teacher was accused of proclaiming doctrines contrary to the Christian religion. According to the reports of questioning the witnesses, Fábián indeed organised a group among the inhabitants of Békés, whom the witnesses (chief judge, pastor, presbyters, preceptor, and local residents) considered atheists and naturalists. One member of the group, Mihály Barkó, an assistant teacher, said that all Frenchmen are naturalists; therefore, they are the bravest and most honest people in the whole of Europe. Fábián claimed in his defence that it was not him who spread the doctrines, but one evening a wandering student visited his house, and, accompanied by other teachers, they discussed the naturalist dogmas raised against Christianity. According to the decision of the diocese, Fábián was immediately stripped of his position and he was also prohibited to proclaim dogmas against Christianity. ${ }^{11}$

Statements reminiscent of deism can be found in the proceedings of the ecclesiastical disciplinary lawsuit conducted against Sándor Úri, the chaplain of Gyoma, in 1802. During the process, he was accused of blasphemy, because he claimed that God himself had broken the second commandment, when he ordered cherubs to be made as the guards of the Ark of the Covenant. Indeed! God doubted his own divinity, when in the body of Christ was born to human. These words are obviously outrageous for believers, but these issues are not relevant with regard to the topic of this study. It is much more important that during the questioning of a witness, Mrs. János Szendrei (a 53 year old inhabitant of Gyoma) says that, according to the pastor, the Bible does not contain the pronouncements of God, but it is only compiled by humans. Úri then replied to this 
accusation that the daft audience misunderstood him, because he proclaimed to them that nowadays there are philosophical trends which deem the Bible a human creation; however, he never said that he agreed. This was all the more so important since the testimony of Mrs. János Szendrei was made long after Úri was denounced with blasphemy. In other words, the first accusations did not involve indications about the dissemination of deism. Nonetheless, during the investigation of the case, the spreading of deist ideas also appeared as a further point of accusation, which implied that the certain elements of deism had already been known by the populace. $^{12}$ As a result of the sentence of the court, Úri was forbidden to practise his profession, but a few years later he successfully passed the exams and he was ordained as a pastor. Until his death he served in the Békés Reformed Diocese, but he never stayed more than a few years in a given congregation, because he was always in conflict with his believers (Szász 2013, 181).

Debeljácsa was founded by Calvinist settlers in the military border-guard zone at the end of the 18th century. At the same time, they established the congregation as well, but the life of this congregation was far from being as organized as in other communities of the diocese: For a long time, the village had no permanent pastor and the religious life was not so intensive either. It can be probably explained by the fact that among the settlers there were people who fled to the border-guard region from the law. In 1805, János Kovács, a local resident, was reproached by the pastor for denying divine providence and Kovács claimed that he would be able to write another Bible. What was more! He even doubted God's existence. In spite of his anti-religious pronouncements, his case was not presented to the diocese; the pastor was pleased that the statements had been withdrawn and he made Kovács promise that he would regularly be taking part in the Communion (Csete-Szemesi 1994, 74).

The last incident happened in Köröstarcsa in 1811: Mihály Papp, the notary, was drunk when he went to the examination of school girls and he scandalised the people there with his revelations, since he said that hell did not exist, but church was eventually a hell for him. He denied Jesus' redemptive nature and called Virgin Mary a whore and Jesus a bastard. All the while, he scorned the Catholic Church, because, according to them, the salvation of Man may change in the purgatory. Many people (e.g., Mihály Újhelyi, a local freeholder) denounced the notary which showed the great indignation of the inhabitants. Afterwards, the ecclesiastical court examined the case. During the examination, it turned out that Mihály Papp participated in a dinner in Békés some years before the accusation where they were talking about the teachings of anti-religious naturalism (The attestation did not specify what these doctrines were, but it ought to be kept in mind that János Fábián had already organised an anti-religious community in Békés in 1796). Finally, the judges obliged Mihály Pap to repent his sins publicly, which he eventually accepted, so he could avoid the laic court proceedings, which could even sentence him to endure corporal punishment. ${ }^{13}$

On the basis of the above described cases, I intend to examine how far and to what extent deism spread in folk religiosity in the Békés Reformed Diocese.

After investigating the available empirical data and information, it can be concluded that both laymen and clergymen made critical statements about religion. At the end of the 18th century, besides pastors and chaplains, teachers counted as clergymen as well, because the profession of teaching was a kind of preparation for the pastoral exam: Most candidates were teacher before they had sought the consecration (Dankó 1988, 776). Among the lay people coming into contact with anti-religiosity, one can find leading intellectuals (doctors, chief caretaker), and peasant men and women, too. Consequently, the question arises to what extent the phenomenon that occurred in the Békés Reformed Diocese can be regarded as pertaining to folk religiosity. In 
my opinion, it can be considered so, because from the perspective of folk religiosity not only people engaged in agricultural activities but also all those laymen who do not have a degree or training in theology may be considered as belonging to the people. ${ }^{14}$ In addition, the conflicts between the pastor and the congregation are really suitable for reconstructing rural social norms and ethics, because on the basis of the denunciations it can be concluded that those problems are what bothers the religious system of values of a community (Bárth 2013). So beside the critical statements of the teachers and chaplains, regarding religion the reactions of the community are much more important and interesting, because from these one can conclude on the nature of folk religion.

In each of the studied settlements, there were lay people who formulated their ideas about religion: András Konkoly, presbyter in Öcsöd, Ferenc Glück in Gyula, the presbytery of the Reformed Church in Békés, Mrs. János Szendrei in Gyoma, János Kovács in Debeljácsa, and Mihály Pap as well as Mihály Újhelyi in Köröstarcsa. However, their attitudes are not identical: János Kovács and Mihály Pap doubted the doctrines of Christianity, while others defended those. It seems that critical thoughts about religion are interesting for not only individuals but for major communities as well, since János Fábián creates a community that is also noticed by Mihály Pap, the notary of Köröstarcsa. On the basis of these considerations, it is plausible to assume that the anti-religiousness of radical Enlightenment is frequently present in everyday life, since in Gyoma even a peasant woman notices these thoughts. Nevertheless, it is another question that to what extent these phenomena might resemble the doctrines and ideas of deism.

Moreover, it seems that the philosophical thoughts spreading through orality creates a medley of the critical doctrines radical Enlightenment nurtured in relation to religion. In several cases, one is informed that the person who voices his or her religious criticism reads no philosophical study at all, but he/she is only informed about the changes from oral sources (e.g., teacher of Öcsöd or the peaceful dinner of Mihály Pap in Békés). Furthermore, the sources nowhere call the anti-religious statements deism, but rather term them scoffer of religion, naturalist, or atheist. It can be explained by the fact that in Hungary the expressions of atheist, deist, theist, naturalist, materialist, pantheist, indifferentist, Spinozist, libertine have the same meaning, namely anti-religiosity, and thus they could not differentiate among them (Balázs 2013, 50-52).

When looking at all the cases meticulously, it can be seen that hardly any settlement can be found where only the traces of deism could be discerned purely. The only exception is the lawsuit of János Fábián, in all the other cases, deist thoughts are supplemented by others. The notary of Köröstarcsa, insisting on the doctrines of the Reformed Church, poked fun at Catholicism, while, approaching to the natural religion, he denied the divinity of Jesus. The blasphemy of Sándor Úri is also mixed with deism (the Bible is only an artefact created by humans). In addition, the accusation of religion-criticism is also involved in the political prosecution in Gyula, and the teacher in Öcsöd had no idea about which philosophical trend denied the resurrection. The settler of Debeljácsa, János Kovács went definitely the farthest, as he also denied the presence of God, while he preached about the total lack of divine providence, the most typical characteristic of deism.

In sum, it can be argued that the Reformed communities of the south eastern region of the Kingdom of Hungary know deism, but they are not aware of the essence of this philosophical trend, because they mix it with other trends of the radical Enlightenment. 


\section{Notes}

1. Israel 2011, 283-96; 302-10. Kasper 2006, Vol. 3; 2006, 60-61.

2. Josephinism is a specific variant of enlightened absolutism, which is understood as the sum of different governance methods of Joseph II.

3. Vovelle 1973. Tüskés-Knapp, 1996, 559-74.

4. Vermes 2014, 153-61. Holzhey 2014, 1373-89. Balázs 2013, 154.

5. German literature distinguish between Calvinist and Reformed because they strictly understand Calvinist as the followers of Calvin's doctrines, while they interpret Reformed as the those who accept the Second Helvetian Creed, which in turn include the doctrines of Calvin, Zwingli, and others. However, Hungarian literature do not make such a distinction; therefore, this study uses the expressions of Calvinist and Reformed as synonyms.

6. Kis 1992, 79-81. Kovách 1998, 340-9. Kosáry 1987, 68-75. Kósa 1999, 268-74.

7. Kókay 1983, 170-1. Fehér 2009, 84-90. Labádi 2007. Tóth 2000, 78-81; 86-89.

8. TtREL I.1.b.35.595. TtREL I.29.h.1. Canonical visitation in Öcsöd, November 22, 1794.

9. Benda 1952, 194-5; 217; 231. Maday 1956. Elek 1985, 68-71.

10. BML IV/A/1/b nr. 207.

11. TtREL I.1.b.36.644. TtREL I.1.b.37.658.

12. TtREL I.1.b.42.807.

13. TtREL I.1.b.51.1048. TtREL I.29.i.100.

14. For the question of the notion of folk religiosity, see: Burke 2009, 201-53. Burke 1988.

\section{Works Cited}

Balázs, Péter. Biblia, história, bölcselet a felvilágosodás korában (Bible, History, and Philosophy in the Age of Enlightenment). Budapest: L'Harmattan, 2013.

Bárth, Dániel. “Alsópapság és népi kultúra (Lower Clergy and Popular Culture).” Ed. Bárth Dániel. Alsópapság, lokális társadalom és népi kultúra a 18-20. századi Magyarországon (Lower Clergy, Local Society, and Popular Culture in Hungary in the 18th-20th Centuries). Budapest: ELTE BTK Folklore Tanszék, 2013. 9-42.

Benda, Kálmán. A magyar jakobinusok iratai (Documents of the Hungarian Jacobins) 3. Vol. Naplók, följegyzések, röpiratok (Diaries, Notes, and Pamphlets). Budapest: Akadémiai Kiadó, 1952.

Benitez, Miguel. La face cachée des Lumières. Recherches sur les manuscrits philosophiques clandestins de l'âge classique (The Hidden Face of Enlightenment. Research on Clandestine Philosophical Manuscripts of the Classical Age). Paris and Oxford: Universitas and Voltaire Foundation, 1996.

Bucsay, Mihály. Die Protestantismus in Ungarn. Teil. 1-2 (Protestantism in Hungary. Part 1-2). Wien: Böhlau, 1977.

Burke, Peter. Popular Culture in Early Modern Europe. Farnham: Ashgate, 2009.

Burke, Peter. "What is Historical Antrophology?" Ed. Burke Peter. The Historical Anthropology of Early Modern Italy. Cambridge: Polity Press, 1988. 3-7.

Dankó, Imre. "A kollégium partikularendszere (The System of Particles of the College)." Ed. Barcza József. A Debreceni Református Kollégium története (The History of the Reformed College of Debrecen). Budapest: Magyarországi Református Egyház, 1988. 776-810.

Elek, László. “A jakobinus mozgalom és a felvilágosodás két üldözött Békés megyei képviselője: Réz József és Fábián János (Two Békés County Representatives of the Jacobin Movement and Enlightenment: József Réz and János Fábián).” Ed. Elek László. Müvelödés és irodalom Békés megyében. 1. Vol. A XVI. századtól a XIX. század derekáig (Education and Literature in Békés County from the 16th Century to the Mid-19th Century). Békéscsaba: Békés Megyei Múzeumok, 1985. 64-77.

Fehér, Katalin. Népfelvilágositó törekvések Magyarországon 1777-1849 (Popular Enlightenment Endeavours in Hungary 1777-1849). Budapest: Mati, 2009.

Csete-Szemesi, István. A debeljácsai (torontálvásárhelyi) református egyház gyökerei, 200 éves múltja és jelene [The Roots of the Reformed Church of Debeljács (Torontálvásárhely), Its 200 Years History and Present]. Budapest: Márton Áron, 1994.

Geertz, Clifford. "Religion as a Cultural System." Ed. Michael Banton. Anthropological Approaches to the Study of Religion. London: Tavistock Publications, 1966. 1-46.

Holzhey, Helmut-Mudroch, Vilem. Die Philosophie des 18. Jahrhunderts. Heilige Römische Reich Deutscher Nation. Schweiz. Nord- und Osteuropa (The Philosophy of the 18th Century. The Holy Roman Empire of the German Nation. Switzerland. Northern and Eastern Europe). Basel: Schwabe, 2014. 
Hegyi Ádám. ““... kik hogy másoknál böltsebbeknek láttassanak, a vallást tsúfolják...’ A vallásellenesség problémája a szentesi református gyülekezetben a 18-19. század fordulóján ('... who want to be seen as more clever than others, those scorn religion...' The Problem of Anti-Religiosity in the Reformed Congregation of Szentes at the Turn of the 18th-19th Century)." Collegium Doctorum Magyar Református Teológia (College of Doctors Hungarian Reformed Theology) 9 (2013): 107-24.

Israel, Jonathan. Democratic Enlightenment. Philosophy Revolution and Human Rights 1750-1790. New York: Oxford UP, 2011.

Kasper, Walter. Lexikon für Theologie und Kirche (Lexicon for Theology and Church). Freiburg and Basel and Wien: Herder, 2006.

Kis, Bálint. A Békési-Bánáti Református Egyházmegye története (The History of the Reformed Diocese of Békés-Bánát). Békéscsaba and Szeged: Csongrád Megyei Levéltár, 1992.

Kiss, Réka. "Református egyházfegyelmi iratok elemzési lehetőségei-koraújkori példák (Possibilities of Interpretation of the Documents of Calvinist Church Discipline-Examples from the Early Modern Age).” Ed. Ágnes Fülemüle and Réka Kiss. Történeti forrás-néprajzi olvasat (Historical Source-Ethnographical Interpretation). Budapest: L'Harmattan, 2008. 316-39.

Kókay, György. “Javaslatok 1789-ből a könyvolvasás népszerüsítése érdekében (Proposals from 1789 in Favour of Popularising Book Reading)." Ed. Kókay György. Könyv, sajtó és irodalom a felvilágosodás korában (Book, Press and Literature in the Age of Enlightenment). Budapest: Akadémiai Kiadó, 1983. 167-77.

Kósa, László. "From the Beginnings to the 18th Century." A Cultural History of Hungary, Vol. 1. Budapest: Corvina and Osiris, 1999.

Kosáry, Domokos. Culture and Society in 18th Century Hungary. Budapest: Corvina, 1987.

Kovách, Géza. A Bánság demográfiai és gazdasági fejlödése 1716-1848 (The Demographical and Economic Development of the Bánság 1716-1848). Szeged: Csongrád Megyei Levéltár, 1998.

Kovács, Ábrahám. Hitvédelem és egyháziasság. A debreceni új ortodoxia vitája a liberális teológiával (Apologetics and Ecclesiastics. The Debate of the New Orthodoxy of Debrecen with Liberal Theology). Budapest: L'Harmattan, 2010.

Kristóf, Ildikó Sz. “A számoktól a (jogi) szövegekig: alfabetizációtörténet, olvasástörténet vagy kommunikációtörténet [From Numbers to (Legal) Texts: History of Literacy and Reading or History of Communication]?” Acta Papensia (Papers Published in Pápa) 6 (2002): 3-28.

Labádi, Gergely. "Az olvasó pásztor. A könyv médiuma a felvilágosult népnevelésben (The Reading Pastor. The Book as a Medium in Enlightened Folk Education).” Erdélyi Múzeum (Museum of Erdély) 3-4 (2007): 61-78.

Lukácsi, Zoltán. "Szószék és világosság. A magyar katolikus prédikáció a 18-19. század fordulóján (Pulpit and Clarity. Hungarian Catholic Preaching at the Turn of the 18th-19th Century).” Ed. Anna Keszeg and Gábor Vaderna. Prima manus. Tanulmányok a felvilágosodás korának magyar irodalmából (Studies from the Hungarian Literature of the Age of Enlightenment). Budapest: Ráció, 2008. 61-73.

Maday, Pál. "A Békés megyei jakobinusok pere (The Trial of the Békés County Jacobins).” Körös Népe (People of Körös) 1 (1956): 127-51.

Schmidt, Heinrich Richard. "Moral Courts in Rural Berne during the Early Modern Period.” Ed. Karin Maag. The Reformation in Eastern and Central Europe. Aldersot: Ashgate, 1998. 155-81.

Szabó, Ferenc. "Az Alföld a 18. századtól a 20. század derekáig (The Great Hungarian Plain from the 18th Century to the Mid-20th Century).” Ed. Ferenc Szabó. Két és fél évszázad az Alföld történetéböl (Two and a Half Centuries from the History of the Great Hungarian Plain). Szeged: Csongrád Megyei Levéltár, 2008. 137-210.

Szász, Lajos. "A református lelkész és gyülekezete a 19. század első évtizedeiben (The Calvinist Pastor and His Congregation in the First Decades of the 19th Century).” Ed. Bárth Dániel. Alsópapság, lokális társadalom és népi kultúra a 18-20. századi Magyarországon (Lower Clergy, Local Society and Popular Culture in Hungary in the 18th-20th Centuries). Budapest: ELTE BTK Folklore Tanszék, 2013. 178-95.

Tüskés, Gábor-Knapp, Éva. Volksfrömmigkeit in Ungarn (Popular Piety in Hungary). Dettelbach: Röll, 1996.

Tóth, István György. Literacy and Written Culture in Early Modern Central Europe. Budapest: CEU Press, 2000.

Vermes, Gábor. Hungarian Culture and Politics in the Habsburg Monarchy 1711-1848. Budapest: CEU Press, 2014.

Vovelle, Michel. Piété baroque et déchristianisation en Provence au XVIIIe siècle (Baroque Piety and Dechristianization in Provence in the Eighteenth Century). Paris: Plon, 1973. 


\section{Archival Sources}

Békés Megyei Levéltár (Gyula) (BML) [Békés County Archives (Gyula)].

IV/A/1/b nr. 207. Békés vármegye nemesi közgyülésének iratai. Vizsgálat Réz József szemorvos ügyében, 1795 (Records of the Assembly of Nobles of Békés County. Examination of the Case of József Réz, oculist, 1795).

Tiszántúli Református Egyházkerület Levéltára (Debrecen) (TtREL) [The Archives of the Reformed Diocese of the Trans-Tisza Region (Debrecen)].

I.1.b.35.595. Egyházkerületi közgyülési iratok. Papp János öcsödi tanító fegyelmije, 1795 (Records of the Diocese Assembly. Disciplinary Proceedings of János Papp, Teacher of Öcsöd, 1795).

I.1.b.36.644. Egyházkerületi közgyülési iratok. Fábián János békési iskolamester fegyelmije, 1796 (Records of the Diocese Assembly. Disciplinary Proceedings of János Fábián, Schoolmaster of Békés, 1796).

I.1.b.37.658. Egyházkerületi közgyülési iratok. Fábián János békési iskolamester fegyelmije, 1797 (Records of the Diocese Assembly Disciplinary Proceedings of János Fábián, Schoolmaster of Békés, 1797).

I.1.b.42.807. Egyházkerületi közgyülési iratok. Úri Sándor gyomai káplán fegyelmije heterodoxia miatt, 1803 (Records of the Diocese Assembly. Disciplinary Proceedings of Sándor Úri, Chaplain of Gyoma, on Account of Heterodoxy, 1803).

I.1.b.51.1048. Egyházkerületi közgyülési iratok. Pap Mihály köröstarcsai jegyző ügye, 1812 (Records of the Diocese Assembly. The Case of Mihály Pap, Notary of Köröstarcsa, 1812).

I.29.h.1. Békés-Bánáti Református Egyházmegye iratai. Egyházlátogatási iratok 1786-1843 (Records of the Reformed Diocese of Békés-Bánát. Records of the Canonical Visitations 1786-1843).

I.29.i.100. Békés-Bánáti Református Egyházmegye iratai. Egyházközségekre vonatkozó iratok. Köröstarcsa 1787-1833 (Records of the Reformed Diocese of Békés-Bánát. Records of the Parishes. Köröstarcsa 1787-1833). 